\title{
CORPUS-SUPPORTED SEMANTIC STUDIES: PART/WHOLE EXPRESSIONS IN RUSSIAN
}

\author{
IGOR BOGUSLAVSKY ${ }^{1,2}-$ LEONID IOMDIN $^{1}$ \\ 'Institute for Information Transmission Problems, \\ Russian Academy of Sciences, Moscow, Russia \\ ${ }^{2}$ Technical University of Madrid, Madrid, Spain
}

BOGUSLAVSKY, Igor - IOMDIN, Leonid: Corpus-supported semantic studies: Part/Whole expressions in Russian. Journal of Linguistics, 2019, Vol. 70, No 2, pp. $254-266$.

\begin{abstract}
We investigate valency properties of partials - words and constructions that express the Part/Whole relation, primarily in Russian, offering new observations largely based on the Russian National Corpus. Special attention is given to such lexical units as bol'šinstvo 'majority', men'šinstvo 'minority', čast' 'part', protsent 'percentages', $v$ bol'šinstve svoem 'in its <their, etc.>majority', 'po bol'šej časti 'for the most part', etc.
\end{abstract}

Keywords: corpus, semantics, valency, part-whole

\section{INTRODUCTORY REMARKS}

Various aspects of words and constructions that express the Part/Whole relation (henceforth referred to as partial expressions or partials) have attracted much attention. Yet one extremely complicated aspect of these expressions, namely their valency properties, was not investigated sufficiently until recently. Several years ago, the authors of this paper introduced important concepts and proposed solutions for some of the challenging issues (see Boguslavsky [1], [2], [3]). In this paper, we will supplement the findings of these papers, and offer a number of new observations, largely based on the material of the Russian National Corpus (RNC, www.ruscorpora.ru).

The paper is arranged as follows. Section 2 is focused on the valency structure of the most typical Russian nominal partials - часть 'part', большинство 'majority', меньшинство 'minority' and проиент 'per cent/percentage'. We start with the regular means of valency instantiations and proceed to non-canonical cases. In Section 3, we present the argument properties of a few other partials. Then, in Section 4, we go on to characterize certain microsyntactic constructions belonging to the class of partials. 


\section{PROTOTYPICAL PARTIALS}

\subsection{Valency instantiation options}

If we view the syntactic representation of a sentence as a dependency structure, we can state that an argument A of a predicate P may occupy one of the three logically possible positions with regard to P: (a) P directly subordinates A; (b) P directly depends on A; (c) A and P are not related to each other by any direct dependence. In the (a) case, we will say that the respective valency of $\mathrm{P}$ is filled by A by an active pattern, in case (b) we have a passive valency pattern, while case (c) displays a discontinuous pattern. The valencies of verbs are mostly filled actively, the valencies of nouns may follow an active or, to a lesser extent, a discontinuous pattern, while adjectival and adverbial predicates accept their valencies primarily in the passive manner, even though active or discontinuous patterns are also possible ([4]).

\subsection{The main valencies of partials}

The minimal argument structure of partials consists of two arguments: Whole and Part. In the most typical case, the valency of Whole is instantiated actively - by an NP in the genitive or a prepositional phrase formed by prepositions ИЗ 'from', ОТ 'from, of', or, less frequently, СРЕДИ 'among', while the valency of Part remains unfilled, cf. часть (половина, 30\%) урожая 'part (a half, 30\%) of crops', часть из нас 'a part of us', $10 \%$ от сумль ' 10 percent of the sum'.

Less prototypical filling options for these valencies are illustrated by cases when, in addition to the valency of Whole of a partial, its valency of Part is also filled, via a support verb that represents a value of a lexical function (in the sense of Igor Mel'čuk's Meaning-Text theory, see [9]), namely, Funci, Operi or Laborij, or through a copula. In these cases, taken from RNC, we deal with the discontinuous pattern of valency filling:

(1) Ряд улиц, пересекающихся под прямым углом, образовывал [Oper1(часть)], так сказать, старинную часть города 'A number of streets crossing at right angles formed, so to say, the ancient part of the city'.

In (1), the noun phrase printed in bold fills the valency of Part of the noun yacmb. Similarly, boldface words instantiate the valency of Part of partials in sentences (1-5).

(2) Женщины составляют [Oper1(процент)] сегодня 57 процентов общей численности этой возрастной группы 'The women make up 57 per cent of the totality of this age group today'.

(3) Вратарь - [zero copula] это половина команды 'The goalkeeper is half of the team.

(4) Лютеране составляют [Oper1(меньшинство)] меньшинство среди всех протестантов 'Lutherans are a minority among all Protestants'. 
(5) Большая часть Вселенной состоит [Func1(часть)] из загадочного невидимого вещества, называемого тёмной материей 'The greater part of the Universe consists of mysterious invisible substance, called dark matter'.

In addition, the valency of Part may be instantiated by a dependent genitive NP, which seems quite exotic as normally this pattern is characteristic of the valency of Whole. Compare the following two sentences:

(6) Руководство компании перевело за гранииу 20\% дохода 'The company's leadership transferred abroad $20 \%$ of their income'.

(7) Вложение принесло 20\% дохода 'The investment yielded 20\% income'.

The two sentences (unlike their English equivalents) appear to be very similar. Yet in (6) and (7) the noun доход 'income' fills the different valencies of the partial проиент 'per cent'. In (6), this is the valency of Whole: $20 \%$ of the total income were taken and transferred abroad. In (7), this is the valency of Part: the income brought up $20 \%$ of the total investment. Note that in either case one of the two valencies remains unsaturated.

Below is another example illustrating the instantiation of the valency of Part by a dependent genitive NP with the unfilled valency of Whole:

(8) Воссозданию класса рантье способствует и наше либеральное налоговое законодательство: $13 \%$ подоходного налога - это немного, к тому же многие не платят вообще ничего 'Our liberal tax legislation helps the recreation of the rentier class: $13 \%$ of income tax is not much, besides, many pay nothing at all'.

Here, income tax is $13 \%$ of the total income, which is not specified in the sentence.

There is one more type of constructions in which both the valency of Part and the valency of Whole display non-prototypical instantiations. The valency of Part is filled by the dependent genitive NP, while the valency of Whole is represented by an expression made up by the VP:

(9) Большинство жителей башкирским не владеют, ведь русских в городе живет больше половины, татар - процентов тридиать, а башкир ... всего пятнадиать. 'The majority of residents do not speak Bashkir, since Russians living in the city constitute more than half of the population, Tatars, about thirty percent and Bashkirs, only fifteen.'

The relevant part of (9) - Русских в городе живет больше половины lit. 'Of Russians, in the city live more than half' demonstrates the fact that the valency of Part of the word половина 'half' is filled in by the noun русских 'Russians' (in the genitive) and the valency of Whole is presented with the VP в городе живёm 'live in the city': ,more than half of those who live in the city are Russians'. Similarly, sentence

(10) На Самотлорском месторождении только 4\% нефти, а все остальное — это вода 'At the Samotlor oil field there is only $4 \%$ of oil, and the rest is water'. says that $4 \%$ of what there is at the oil field is oil. 


\subsection{Additional valencies of partials}

So far we have been discussing the partials with two valencies - Part and Whole. However some of the partials have at least three valencies. These include the words большинство 'majority', меньиинство 'minority', and часть (the latter will be discussed in Section 4.2).

The nouns большинство and меньшинство, in addition to the above mentioned valencies, have a third valency of Property. Consider the following definition:

- большинство <меньшинство $>(\mathrm{Q}, \mathrm{R}, \mathrm{P})=$ ' $\mathrm{Q}$ is part of a set $\mathrm{R}$ such that this $\mathrm{Q}$ possesses the property $\mathrm{P}$; this part is greater $<$ smaller $>$ than the remaining part of R'.

This definition can be illustrated by the following example:

(11) Ныне же большинство загадок, ранее казавшихся непостижимыми, благополучно разрешены наукой 'Now the majority of mysteries that earlier appeared to be incomprehensible, are successfully solved by science'.

This sentence means that among the mysteries that seemed unsolvable (Whole) such mysteries that have the Property of being solved by science constitute a greater part of mysteries than those that do not possess this property.

As a rule, the valency of Property is expressed by the VP, as in (11). However, curious variations can be observed here, too. For instance, this valency is very often represented by an adjectival modifier, as in русскоязычное больиинство 'Russianspeaking majority', which refers to the part of the population for which Russian is the native tongue and which exceeds the remaining part of the population, or in наииональное меньшинство 'national minority' ${ }^{1}$. Cf., for example,

(12) На юге жили кхмерские народы; они и сегодня составляют здесь значительное наииональное меньиинство 'Khmer people lived in the south, they constitute a considerable national minority'.

\section{OTHER PARTIALS}

\subsection{Voting majority}

The noun большинство 'majority' has another meaning in addition to the one discussed above: for convenience, we will call it the voting majority and denote as большинство ${ }^{2}$. This lexical unit has a number of features that distinguish it from the

\footnotetext{
${ }^{1}$ Interestingly, this last phrase is in fact an idiom as it denotes a part of the population that belongs to a particular nationality while all other inhabitants of the respective country or territory (not necessarily belonging to one and the same nationality!) outnumber this part. It is worth adding that this idiom may be used in plural: национальные меньиинства 'national minorities' and even has a special abbreviation: наименьиинство. Another example of such phrases is a recently emerged сексуальное меньиинство 'sexual minority': surprisingly, its first occurrence in RNC dates to 1991 and remained exceedingly rare until 2000 .
} 
regular большинство. First of all, its valencies have a different content: (i) Who has majority? (ii) Over whom? (iii) Which number of votes does the majority party have? These properties can be illustrated by sentences like

(13) Лейбористы добились большинства над консерваторами 'The Labor Party achieved a majority over the conservatives'.

(14) Для решения такого вопроса требуется большинство в две трети голосов <семидесятипроцентное большинство> 'To resolve this issue, a twothirds majority $<$ a seventy-percent majority $>$ is needed'.

(15) Альенде сменил президента Эдуардо Фрея Монтальву, который, в отличие от него, был избран небывалым в истории страны большинством в $56 \%$ голосов. 'Allende replaced President Eduardo Frei Montalva, who, by contrast, was elected by a majority of $56 \%$ of votes, unprecedented in the history of the country'.

Interestingly, the quantitative expression introduced by the preposition $b$ (which has in this case a loose English equivalent of) may refer to two different things: it can either denote the number (or share) of votes constituting the majority, as in (14)(15), or the difference between the larger and the smaller part of the votes, as in (16):

(16) Правление большинством, правда, всего в один голос (четыре против трех), проголосовало за вас. 'The board voted for you, albeit by a majority of only one vote (four against three)'.

The difference between the larger and the smaller part may also be expressed by the preposition на 'by', which is rather rare and obsolete but attested by the corpora:

(17) И тогда у Ленина образовалось большинство на один голос. 'Then Lenin achieved a majority of one vote'.

It is curious that the same fragment of meaning - the difference between the larger and smaller parts - may be conveyed by an adjective. Незначительное больиинство 'slim <narrow> majority' does not mean that the majority has a small (or negligible) number of elements but that its difference from the minority is small. So we have here a non-compositional phrase, almost an idiom. Amusingly enough, the phrase незначительное меньшинство 'small minority' has the meaning that should be expected: it includes very few elements.

Another distinctive feature of большинство ${ }^{2}$ is the fact that it can be used in the instrumental case, denoting a mode of action, as in (15) - (16) above.

Finally, the word has a very specific lexical combinatorics; cf. such expressions as простое большинство 'simple majority' or квалифицированное большинство 'qualified majority'.

\subsection{Percentage}

The noun проиент 'percentage' has a specific use which emerges when it stands in the singular and has no dependent numeral: we will refer to it as nроиент ${ }^{2}$. For example, 
(18) Проиент недовольных растет 'The percentage of discontented people is growing'

does not mean that the hundredth part of those discontented is increasing but that the number of such people, expressed as per cent of the whole population is growing. Similar to (9)-(10) above, the NP in the genitive (недовольных) instantiates here the valency of Part, and not Whole.

Thus, the neutral usages of expressions like большинство студентов 'the majority of students' and часть студентов 'part of students', on the one hand, and проиент студентов 'percentage of students', on the other hand, need different interpretations: in the first case, students are the enveloping set and in the second case they are a part of the enveloping set. Hence, the expression процент студентов в городе 'percentage of students in the city' implies that the city also has nonstudents, while the phrase больиинство студентов в городе 'the majority of students in the city' does not presuppose any involvement of non-students.

\subsection{The larger part}

the expression большая часть 'the larger part' has two essentially different interpretations: (a) part of a whole that is greater than some other part of this whole, and (b) part of a whole that is greater than the remaining part of the whole. The first interpretation is seen in

(19) Каждый год ситуаиия будет ухудшаться - либо придется повышать налоги, отнимая у людей все большую часть заработной платы, либо придется уменьшать пенсии. "With every year the situation will worsen - either one will have to raise taxes, taking away a bigger and bigger part of the salary from people, or one will have to cut pensions'.

Here, большая часть has a standard interpretation of the comparative (a): one will take away a part of the salary which will be greater than the part taken away previously.

The second interpretation (b) may be illustrated by the sentence:

(20) У меня отняли большую часть зарплать 'They took away the larger part of my salary' (i.e. took away the part which is larger than the remaining part).

In interpretation (b), the expression cannot be viewed as a comparative (note that it cannot accept a comparative conjunction чем 'than'). In this case большая часть 'the larger part' is idiomatic and represents a microsyntactic construction, largely synonymous to the word большинство 'majority' (with the exception that большинство requires a whole that can be counted, cf. большая часть наследства 'the larger part of the heritage' but not *большинство наследства 'the majority of heritage').

\subsection{By half}

Russian has several units whose meaning is related to 'half'. These are the noun половина 'half', adverbs пополам, наполовину, вполовину 'by half', the numeral 
пол and prefix полу- ${ }^{2}$. Below, we will compare наполовину and полу-, which in some contexts manifest curious contrast.

At first sight, these units are very close - cf. pairs (21)-(22) and (23)-(24) where they are synonymous.

(21) Мой отец отличался мягкостью сердиа, легкостью нрава - и целым винегретом из генов: был швейиарский гражданин, полуфраниуз-полуавстриеи, с Дунайской прожилкой. 'My father was a gentle, easy-going person, a salad of racial genes: a Swiss citizen, of mixed French and Austrian descent, with a dash of the Danube in his veins' (Nabokov, Lolita), lit. 'half-French, half-Austrian'; 'half' expressed by prefix полу-.

(22) Мой отеи был наполовину франиуз, наполовину австриеи. 'My father was half French and half Austrian; 'half' expressed by the adverb наполовину.

(23) Она посмотрела на него полуиспуганно-полуудивленно 'She looked at him half-frightened and half-surprised'; 'half 'expressed by prefix полу-.

(24) Она посмотрела на него наполовину испуганно, наполовину удивленно 'She looked at him half frightened and half surprised'; 'half' expressed by adverb наполовину.

It can be noted however that the adverb and the prefix behave somewhat differently. The examples above show that they both form two-element strings: полуфраниуз-полуавстриеи, наполовину франиуз, наполовину австриеи 'half French and half Austrian'. However, наполовину cannot form longer chains, cf.

(22') *наполовину франиуз, наполовину австриеи, наполовину китаеи 'half French, half Austrian, half Chinese',

while the prefix полy- is not bound by this constraint:

(23') Она посмотрела на него полуиспуганно, полуудивленно, полувопросительно 'she looked at him half-frightened, half-surprised and half-questioningly'.

(25) Полу-милорд, полу-купеи, полу-мудреи, полу-невежда, полу-подлеи, но есть надежда, что станет полным наконеи 'half-milord, half-merchant, halfwise man, half-illiterate, half-scoundrel...' (an epigram by Pushkin).

In our opinion, this difference can be explained as follows. When we use наполовину in (23) to say that she looked at him half-frightened and half-surprised, we mean that among the properties of her look, one half is a manifestation of fright and the other one is a manifestation of surprise. This enumeration cannot be extended because nothing can have more (or less!) than two halves. Sentence (23') with the prefix carries a different message. We do not describe two halves of the look. We characterize different components mixed in her look, claiming that the look manifests different feelings and nothing can prevent it from manifesting several feelings at a time. On the other hand, each of them is not presented in its entirety but only

${ }^{2}$ The semantics of this prefix was described in Boris Iomdin ([4]) in much detail. However, the phenomena discussed below were not accounted for. 
partially. It is not real fright, it is only half-fright. Thus, the difference between наполовину and полу- is related to what the whole is from which halves are extracted.

However, prefix полу- can have both interpretations, and it may be difficult to decide which of them is preferable in a concrete case. For example, sentence (26) can mean both (a) 'not quite jokingly, not quite lovingly', and (b) 'each of two pure elements - joke and love - constitutes one half of the whole attitude':

(26) 'Извини, Васьвась, - так, полушутя-полулюбовно, она называла своего мужа, - но это тебя' (А. Якунин) 'Excuse me, Vas'vas', - this is how half-jokingly and half-lovingly she called her husband - but this is for you' ${ }^{3}$

\section{CERTAIN MICROCONSTRUCTIONS}

The expressions discussed below can be viewed as microsyntactic constructions in the sense of Iomdin ([5], [7]) as they have specific syntactic and semantic properties. We will look at two such constructions in sufficient detail.

\subsection{In the majority of cases}

The expression discussed has two variants differing in word order: (a) в больиинстве своём and (b) в своём больиинстве, where the reflexive adjective своём precedes the noun; (a) and (b) are fully synonymous. Basically, this is an adverbial derivate of the noun большинство 'majority', which inherits its major semantic valencies, in particular, the valencies of the Whole and Property. Prototypically this adverbial is dependent on the predicate $\mathrm{P}$ (often expressed by a verb) and semantically refers to its subject $X$, stating the fact that most of the individual entities of the (collective) subject $\mathrm{X}$ are affected by the predicate:

(27) Математики, в большинстве своём, не замечают, что слово «неподалёку» означает нечто большее, чем малость расстояния. 'Mathematicians, in their majority, do not notice that the word 'nearby' means something more than smallness of distance' (Russian mathematician Vladimir Uspensky on the barrier between mathematics and humanitarian science).

In (27), математики 'mathematicians' is X, не замечать 'not to notice' is $\mathrm{P}$, and the adverbial refers to the part of mathematicians which is greater than the part who do not fall under the category of non-noticers. In this case, $\mathrm{X}$ instantiates the valency of Whole, while P instantiates the valency of Property of this adverbial.

By default, $\mathrm{X}$ is expressed by a count noun in plural denoting humans, but corpus data show that these restrictions can be overridden quite easily. Cf.

(28) Человек в большинстве своем слаб (А. Розенбаум) 'Man is for the most part weak',

where человек 'human' is used generically; or

\footnotetext{
${ }^{3}$ We thank Valentina Apresjan for bringing our attention to this example.
} 
(29) Современные приборы в большинстве своем страшно дороги и сложны 'Modern appliances, in their majority, are terribly expensive and complicated'.

What cannot be overridden, though, is the fact that the adverbial must be subject-oriented - probably due to the fact that it contains the reflexive adjective своём 'one's own', whose syntactic behavior in Russian obeys the rule that it should be anaphorically related to the subject of a predicate (and, typically, even to the grammatical subject) - even though the presence of this reflexive adjective is, in our opinion, hardly justified semantically ${ }^{4}$. So, sentences like

(30) Больные уважают врачей в своем большинстве 'Patients respect doctors, for the most part',

where the property $\mathrm{P}$ ('respect') refers to the majority of patients and not to the majority of doctors, notwithstanding the linear sequence of nouns that could, hypothetically, claim to be fulfilling the adverbial's valency of Whole. In (30) this valency is instantiated by the noun that plays the role of the grammatical subject.

A similar restriction seems to hold in the Russian National corpus example

(31) (Согласно статистике, сегодня в России более шести миллионов неполных семей.) В большинстве своём, конечно, детей воспитывают материодиночки. 'According to the statistics, there are over six million one-parent families in Russia today). In the majority of cases, naturally, it is single mothers who raise children':

In (31), the adverbial в большинстве своём refers to the majority of single mothers (also the grammatical subject of the verb) rather than to the majority of children $^{5}$. However, the semantics of this sentence is very different from that of (30). In order to explicate this difference, let us compare two sentences (32) and (33), essentially produced with the lexical material of (31):

(32) Матери-одиночки, в большинстве своём, воспитывают детей без помощи бабушек и дедушек 'Single mothers, in their majority, raise children with no assistance from grandparents';

(33) Воспитывают детей без помощи бабушек и дедушек, в большинстве своем, матери-одиночки lit. 'raise children with no assistance from grandparents, in their majority, single mothers' $\approx$ 'In the majority of cases, it is single mothers who raise children with no assistance from grandparents'.

${ }^{4}$ The etymology of the adverbial and especially the use of the reflexive adjective here require special research, which we cannot undertake now. It is noteworthy however that a similar reflexive pronoun occurs in the equivalents of the microconstruction в большинстве своём in other Slavic languages: Ukrainian (в більшості своїи), Belarussian (у большасиі сваёй), Polish (w większości swojej), and Bulgarian (в по-голямата си част).

${ }^{5}$ Of course, common sense expectations may also bring us to the conclusion that the majority of children from one-parent families are brought up by single mothers - but this is explained by logical inference and not by the lexicographic definition of the adverbial. 
These sentences have identical syntactic structures but different word order and communicative structures, and it turns out that the adverbial в большинстве своём makes essentially different contributions into their semantics. Sentence (32) states that the majority of single mothers raise their children alone. In contrast, sentence (33) says that among all people who raise children with no grandparental assistance the majority are single mothers. This means that the valencies of our adverbial are expressed differently in (32) and (33). As a first approximation, the rule defining the valency instantiation looks as follows: the sentence's Theme fills in the valency of Whole, while its Rheme fills in the valency of the Property. Indeed, in (32) the NP single mothers constitutes the Theme and the remaining VP makes up the Rheme. Accordingly, (32) means 'the majority of single mothers have the property of raising children alone'. In other words, single mothers are the enveloping set (from which a subset of those receiving no help from grandparents is chosen).

In (33), the Theme is formed by the VP (those who raise children alone) and the Rheme is single mothers. By our rule, the meaning of (33) is 'the majority of those who raise children alone have the property of being single mothers'.

Looking back at sentence (31), we find the same situation: single mothers fill in the valency of Property of our adverbial - a different valency that is instantiated by the same NP in (30).

Of special interest is the case where our adverbial refers to a predicate expressed by an adjective, which in its turn plays the role of a modifier of a noun:

(34) Религиозные в большинстве своем граждане Соединенных Штатов уделяют ритуальным услугам особое внимание 'Religious, in their majority, citizens of the United States pay special attention to ritual services' (RNC).

Syntactically, the adverbial is clearly subordinated by the adjective. Yet, semantically, the adjective религиозные 'religious' fills its valency of Property, thus manifesting a passive pattern of valency filling. It should be added that the valency of Whole of our adverbial is instantiated by the noun граждане 'citizens', exemplifying another valency following a passive pattern. Most interestingly, (34) does not specify the valency of Part of the adverbial in any way: there is no evidence that something is peculiar to the religious (or non-religious, for that matter) part of the citizens - their interest in ritual services is stated for the whole body of them, notwithstanding the religiosity of particular persons. It should be added that in constructions like (34) the adjective always acts as a qualificative and not as a restrictive modifier in the sense of Jespersen ([8]).

Note that it is not the only microconstruction to reveal this kind of behavior. The same valency distribution and the qualificative status of the adjective can be seen in the largely synonymous adverbials по больщей части 'for the most part', в основном 'mainly', по преимуществу 'predominantly, par excellence' and the latter's one-word adverb variant преимущественно 'predominantly'; cf. 
(35) Его понтификат проходил на фоне Первой мировой войны ..., когда развалилась Австро-Венгерская империя с католическим по преимуществу населением 'His pontificate took place during World War I... when the AustroHungarian empire with its predominantly Catholic population collapsed' (newspaper subcorpus of RNC).

To conclude the discussion of the microconstruction в больиинстве своём wе would like to make four more comments.

(i) The adverbial в больиинстве своём itself tends to be unstressed and precedes the predicate that instantiates its valency of Property. Normally, however, it does not belong to the Theme of the utterance (and never belongs to the Rheme thereof).

(ii) There are a few other adverbials derived from большинство which do not include the reflexive adjective (e.g. в большинстве случаев 'in the majority of cases', в большинстве ситуаций 'in the majority of situations, or simply в большинстве with no extending words - lit. 'in majority', the latter occurring relatively rarely:

(36) Люди в большинстве не знали, куда вложить ваучер 'The people, in their majority, did not know where to invest their voucher'.

These adverbials do not share the requirement to be oriented to the subject, cf.

(37) Внешняя атрибутика для турков в большинстве важней сути 'For Turks, in their majority, external attributes are more important that the essence'

(iii) In singular cases, the microsyntactic construction may have an additional adjectival modifier of the word большинство: $c f$.

(38) Архитекторы в абсолютном своём большинстве сторонники европейского типа застройки 'Architects in their absolute majority are supporters of the European type of housing'.

Interestingly, such modifiers need not even express the high degree of majority, although in most cases they do. However, in

(39) Но в своих поступках люди, в своём нормальном большинстве, все же руководствуются не снами lit. 'But in their actions people, in their normal majority, are not guided by dreams after all' (newspaper subcorpus of RNC),

the adjective нормальныц 'normal' introduces the third valency of the word большинство and hence of the adverbial under study, namely, the valency of Part. Indeed, in (39) the valency of Whole is expressed by the word люди 'people', the valency of Property is instantiated by the predicate complex руководствоваться не снами (lit. 'not be guided by dreams'), and this property is used to select the subset of people that we want to call normal.

(iv) On the periphery of the lexical system, antonymic constructions for our adverbials can be found, such as в меньшинстве своём 'in their minority'. They are for the most part used ironically, as part of language play, implicitly referring to the situation described by the original construction, as in

(40) Женская половина в меньшинстве своём следит за своим внешним видом. 'The female half, in their minority, care about their looks' 
The occurrences of such potential lexical units are rare and their representation in corpora is negligible.

\subsection{Constructions of the type tret'ja čast'}

In Section 2, we discussed the partial yacmb ${ }^{1}$ 'part'. This noun, however, has a different meaning yacmb ${ }^{2}$ which also belongs to the class of partials but is better considered here as it never occurs independently and forms a special microsyntactic construction. This meaning can be illustrated by (41):

(41) Мэри может рассчитывать на пятую часть наследства 'Mary can count on a fifth of the inheritance'.

The word $4 a c m b^{2}$ 'part' may be given the following definition: $X$ ecmb $N$-aя $4 a c m b^{2} Y-a=$ ' $\mathrm{X}$ is one of $\mathrm{N}$ equal parts $\left(\right.$ yacmb $\left.{ }^{1}\right)$ of $\mathrm{Y}$, which, taken together, constitute $\mathrm{Y}^{\prime}$. Yacmb ${ }^{2}$ differs from $4 a c m b^{1}$, in particular, in the fact that it has an additional syntactically obligatory valency $\mathrm{N}$, denoting the number of equal parts into which the whole is divided, which has to be expressed by an ordinal adjective. The obligatory character of valency $\mathrm{N}$ does not imply that sentences from which such an ordinal adjective is absent will be ungrammatical. It only means that without such an adjective the meaning $4 a \mathrm{cmb}^{2}$ cannot be realized. If we omit the adjective in (41), the idea of the whole being divided into equal parts will disappear and the word часmb will be interpreted as чacmb ${ }^{1}$ :

(42) Мэри может рассчитьвать на часть ${ }^{1}$ наследства. 'Mary can count on a part of the inheritance'.

The word $4 a \mathrm{cmb}^{2}$ is related with a whole set of words who share the following property: in the meaning of these words the variable $\mathrm{N}$ is filled in by a concrete number: половина, вторая ( $\mathrm{N}=2)$ 'а half', треть, третья $(\mathrm{N}=3)$ 'a third', четверть, четвертая $(\mathrm{N}=4)$ 'а quarter; пятая $(\mathrm{N}=5)$, 'a fifth', шестая $(\mathrm{N}=6)$ 'а sixth' etc. The nominalized adjectives belonging to this list may be presented as the result of omission ${ }^{6}$ of the noun часть ${ }^{2}$ in phrases like пятая часть ${ }^{2}$. An interesting difference, however, can be observed: in contrast to phrases like пятая часть ${ }^{2}$, the nominalized adjectives require a numeral:

(43) Мэри может рассчитьввать на одну пятую <две пятых, три пятых > наследства. 'Mary can count on a fifth $<$ two fifths, three fifths $>$ of the inheritance'. but not

(44) * Мэри может рассчитывать на пятую наследства.

Despite the fact that this numeral is syntactically compulsory, it does not form a new valency, but is a normal modifier.

To complete the account of this microsyntactic construction, we should add that it has a closely synonymous construction formed with the word доля 'share' which is gradually becoming obsolete: третья доля 'a third', милионная доля 'a millionth'

\footnotetext{
${ }^{6}$ In much the same way, constructions like nяmое марma (and its English equivalent the fifth of March) can be viewed as omissions of the word число or day, resulting in the nominalization of the ordinal adjectives.
} 
etc. It has curious peculiarities differing it from the word $4 a \mathrm{cmb}^{2}$ (mainly of selectional restriction nature) but they fall out of scope of this paper.

\section{CONCLUSION}

We have studied a class of expressions with the meaning of parts of a whole, involving individual words and microsyntactic constructions. We were primarily interested in valency properties of these expressions, choosing the material from the Russian National Corpus and a few other resources. Due to this approach, we were able to find and explain a number of interesting phenomena which eluded researchers' observation so far.

\section{ACKNOWLEDGMENTS}

This work was partly supported by a grant No. 16-18-10422-P from the Russian Scientific Foundation, which is greatly appreciated.

\section{References}

[1] Boguslavsky, I. (2005). Valencies of Quantifying Words. [Валентности кванторных слов.] // Kvantitativnyj aspect jazyka. Moscow, pages 139-165. (In Russian).

[2] Boguslavsky, I. (2013). Adverbial partials in Russian (vdvoe 'twice as much/half', napolovinu 'half' and others). In Proceedings of the $6^{\text {th }}$ International Conference on Meaning-Text Theory Prague, August 30-31, 2013. Eds. V. Apresjan, B. Iomdin, and E. Ageeva. Available at: http: // meaningtext. net/mtt2013/proceedings

[3] Boguslavsky, I. (2018). Partial expressions in Russian. [Парциальные выражения в русском языке.] Voprosy jazykoznanija, 2, pages 29-52. (In Russian).

[4] Iomdin, B. (2003). The semantics of the Russian Prefix POLU-. [Семантика русской приставки ПОЛУ- ] // Rusistika na poroge XXI veka: problem I perspektivy. In Proceedings of an international scientific conference (Moscow, 8-10 June 2002), pages 109-113. Moscow, Institute of Russian Language. (In Russian.)

[5] Iomdin, L. (2017a). Between a syntactic idiom and a syntactic construction. Nontrivial cases of microsyntactic ambiguities. [Между синтаксической фраземой и синтаксической конструкцией. Нетривиальные случаи микросинтаксической неоднозначности.] SLAVIA, с̌asopis pro slovanskou filologii, 86(2-3), pages 230-243. (In Russian.)

[6] Iomdin, L. (2017b). Microsyntactic annotation of Corpora and its use in Computational Linguistics Tasks. Jazykovedný časopis, 86(2), pages 169-178.

[7] Iomdin, L. (2018). Once again on microconstructions formed by functional words. To i delo. [Еще раз о микроконструкциях, сформированных служебными словами: То и дело.] // Computational Linguistics and Intellectual Technologies. International Conference (Dialog '2018), pages 267-283. Moscow, RGGU Publishers, 17(24). (In Russian.)

[8] Jespersen, O. (1933). Essentials of English grammar. London, Allen \& Unwin.

[9] Mel'čuk, I. (2014). Semantics: From Meaning to Text. Vol. 3. Amsterdam, John Benjamins Publishing Company. 